DOI https://doi.org/10.30525/978-9934-588-46-4.04

\title{
МІСЦЕВЕ УПРАВЛІННЯ В УКРАЇНІ: ПРОБЛЕМИ ТА ШЛЯХИ ЇХ ВИРІШЕННЯ
}

\author{
Карпа М. І., Акімов О. О.
}

\section{ВСТУП}

Актуальність теми статті зумовлена децентралізаційними процесами в Україні, зміщенням владно-управлінських впливів від державних до самоврядних інституцій, розподілом повноважень між публічними інституціями на місцевому рівні та їх посадовими особами, формуванням нової концепції місцевої влади, розвитком партнерства та координації в публічно-управлінській діяльності на місцях. Об'єктом дослідження є сфера публічного управління, а предметом дослідження - здійснення публічно-управлінської діяльності на місцевому рівні. Метою дослідження $є$ визначити проблемні питання процесів здійснення місцевого управління в Україні та запропонувати можливі шляхи їх вирішення з позиції науково-дослідницького та практичного підходів. Для досягнення мети визначено два завдання, аналіз і висновки до яких відображені у двох частинах статті.

У першій частині статті проаналізовано стан і проблеми здійснення місцевого управління в Україні. Зокрема, зазначені тенденції розвитку громад i територій, проаналізовано стан реформування місцевого управління та виявлені проблеми місцевого управління в Україні.

Друга частина статті включає два блоки, у яких запропоновано рекомендації щодо вирішення проблемних питань, пов'язаних зі здійсненням управлінської діяльності на місцевому рівні.

Актуальність дослідження підтверджена наявністю проблемних питань у здійсненні управлінської діяльності публічними інституціями та їх співвідношення на місцевому рівні. Управлінська дія, яка має бути спрямована зазвичай на вирішення питань місцевого рівня, а саме інтересів територіальних громад, окремих громадян передбачає наявність попереднього узгодження, але публічність у цьому контексті має більше дорадчий, консультативний характер. Сьогодні з метою врахування інтересів територіальних громад під час розроблення 
проекту перспективного плану уповноважені облдержадміністрацією посадові особи проводять консультації 3 уповноваженими представниками органів місцевого самоврядування та їхніх асоціацій, а також суб'єктами господарювання та їхніми громадськими об'єднаннями ${ }^{1}$. Державна й муніципальна влада традиційно й до сьогодні орієнтується на розвиток сфер державного та місцевого господарства. Сучасні тенденції публічного управління зорієнтовують владу до визначення питань державного та місцевого значення, закріплення їx у нормативному полі, здійснення розмежування компетенцій органів публічної влади на місцевому рівні. Закріплення конкретних предметів відання на місцевому рівні (у вужчому сенсі - за об'єктним і територіальним принципом) суб'єктів місцевого управління сприятиме розширенню самостійності суб'єктів на місцевому рівні, збільшенню децентралізаційних процесів, розмежує функції та повноваження органів виконавчої влади й місцевого самоврядування, збільшить відповідальність територіальних громад, ураховуватиме специфіку локальної території².

Об'єкти місцевого управління, зокрема питання місцевого значення, є способом юридичного зазначення тих сфер місцевого життя, які визначаються як предмет власних дій органу місцевого самоврядування. Натепер в Україні об'єкти місцевого управління зазначені в нормативному полі десятками позицій, тоді як їх реальна кількість $\epsilon$ набагато більшою, що потребує визначення та фіксації їх кількості, закріплення компетенцій за кожним із них, визначення суб'єктів їх управління. Компетенція формує власні дії органів місцевого управління, територіальних громад, посадових осіб органів місцевого самоврядування.

\section{1. Стан і проблеми місцевого управління в Україні}

У лютому 2020 року міністр розвитку громад та територій анонсував, що невдовзі в регіонах проведуть широкі публічні дискусії стосовно підготовки пропозицій змін до Конституції України щодо реформування системи місцевого самоврядування й

1 Про затвердження Методики формування спроможних територіальних громад : Постанова Кабінету Міністрів України від 08.04.2015 № 214. URL: http://zakon2.rada.gov.ua/laws/show/214-2015-\%D0\%BF/paran10\#n10 (дата звернення: 02.03.2020).

2 Карпа M.I. Формування компетенції органів публічної влади: територіально-орієнтований підхід. Ефективність державного управління : збірник наукових праць / ЛРІДУ НАДУ. 2017. Вип. 3. С. 213-222. 
територіальної організації влади, децентралізації владних повноважень. Уже сьогодні уряд упровадив такі підходи до формування спроможних громад: визначив критерії оцінювання рівня спроможності громади, тобто іiї людського потенціалу, фінансових і майнових ресурсів, які дадуть змогу надавати якісні послуги жителям, вирішувати накопичені проблеми, розвивати місцеву економіку. Планується, що до квітня 2020 року в Україні вже буде затверджений адміністративно-територіальний устрій базового рівня, до червня - субрегіонального рівня. У третьому кварталі очікується прийняття нової редакції Закону України «Про місцеве самоврядування в Україні» та необхідних змін до Податкового та Бюджетного кодексів. Четвертий квартал прийняття актів, спрямованих на виконання названих законів ${ }^{3}$.

В Україні процес децентралізації розпочато 2014 року з прийняттям Концепції Реформи місцевого самоврядуванння та територіальної організації влади (01.04.2014), Законів України «Про співробітництво територіальних громад» (17.06.2014), «Про добровільне об'єднання територіальних громад» $(05.02 .2015)$ та змін до Бюджетного й Податкового кодексів щодо питань фінансової децентралізації. Цей процес дав змогу формувати відповідно до положень Європейської хартії місцевого самоврядування значний дієвий i спроможний інститут місцевого самоврядування на базовому рівні - об'єднані територіальні громади (ОТГ $)^{4}$. Сьогодні вже створено 1045 ОТГ, 3 них у 2015-2018 рр. створено 805, у 2019 р. $-176^{5}$.

В Основному Законі України передбачено форми та засоби реалізації права територіальних громад на місцеве самоврядування й указано, що органи місцевого самоврядування в межах повноважень, визначених законом, приймають рішення, які $\epsilon$ обов'язковими до

${ }^{3}$ Реформа децентралізації завершиться в 2020 році проведенням восени місцевих виборів на новій територіальній основі громад. Єдиний веб-портал органів виконавчої влади України. URL: https://www.kmu.gov.ua/news/reformadecentralizaciyi-zavershitsya-v-2020-roci-provedennyam-voseni-miscevih-viborivna-novij-teritorialnij-osnovi-gromad (дата звернення: 02.03.2020).

4 Реформа децентралізації. Єоиний веб-портал органів виконавчої влади Украӥни. URL: https://www.kmu.gov.ua/ua/diyalnist/reformi/reformadecentralizaciyi (дата звернення: 02.03.2020).

5 Офіційний веб-сайт Державної казначейської служби України. URL: https://www.treasury.gov.ua/ua/kaznachejstvo-informuye/obyednani-teritorialnigromadi (дата звернення: 02.03.2020).

60 
виконання на відповідній території (частина 1 статті 144) 6 . На основі цього положення Конституції України в Законі визначено, що у формі рішень рада приймає нормативні та інші акти (частина 1 статті 59). Проаналізувавши функції й повноваження органів місцевого самоврядування, врегульовані Конституцією України та іншими законами України, Конституційний Суд України дійшов висновку, що органи місцевого самоврядування, вирішуючи питання місцевого значення, представляючи спільні інтереси територіальних громад сіл, селищ і міст, приймають нормативні та ненормативні акти. До нормативних належать акти, які встановлюють, змінюють чи припиняють норми права, мають локальний характер, розраховані на широке коло осіб і застосовуються неодноразово, а ненормативні акти передбачають конкретні приписи, звернені до окремого суб'єкта чи юридичної особи, застосовуються одноразово й після реалізації вичерпують свою дію. Такий висновок узгоджується 3 правовими позиціями Конституційного Суду України, викладеними в рішеннях від 27 грудня 2001 року № 20-рп/2001'

Реформування місцевого управління потребує вирішення низки проблем, які виникають як у практичній площині, так і в питаннях теоретико-методологічного забезпечення. Варто зазначити, що в нормативному та практичному полі виникають суперечності й неоднозначності щодо питань місцевого значення як об'єктів управлінської діяльності органів місцевого самоврядування, зокрема щодо їх визначення, фіксації в нормативному полі, використання в практиці управління. Тому актуальним є питання визначення об'єкта управління на місцевому рівні. У законодавстві України за цим змістовим визначенням діє поняття «питання місцевого значення».

Для визначення об'єктів місцевого управління, їх змісту доцільно вибрати такі критерії:

- компетенційний критерій (об’ єкти знаходяться в компетенціях органів місцевого управління);

- територіальний критерій (об'єкти знаходяться в межах території відповідної території);

${ }^{6}$ Конституція України : Закон України від 28.06.1996 № 254к/96-BP. URL: http://zakon3.rada.gov.ua/laws/show/254к/96-вр (дата звернення: 02.03.2020).

7 Рішення Коституційного Суду України у справі за конституційним поданням 139 народних депутатів України від 27.12.2001 № 20-рп/2001. URL: http://zakon3.rada.gov.ua/laws/show/v020p710-01 (дата звернення: 02.03.2020). 
- предметний критерій (об'єкти мають виражену предметну форму, тобто матеріальне, процедурне, управлінське визначення);

- процедурний критерій (вирішення питань щодо об'єктів управління передбачає управлінську дію).

Об'єкт місцевого управління - це сфери місцевого суспільного існування, у яких діють компетенції органів публічної влади місцевого рівня. Кожний $з$ органів місцевого управління має мати свої компетенційне поле для здійснення управлінської діяльності, яке визначене нормативно-правовими положеннями. Отже, об'єкти місцевого управління можна вважати способом нормативного визначення сфер суспільного життя, які проявляються як предмет публічно-управлінської діяльності на місцевому рівні.

У вітчизняну нормативно-правовому полі існує досить узагальнений підхід до визначення об'єктів місцевого управління, у тому числі питань місцевого значення. Через таку ситуацію виникають проблеми практичного характеру - неефективна реалізація функцій управління органами влади, перевищення повноважень суб'єктами управління, бездіяльність щодо об'єктів управління тощо.

3 огляду на положення Європейської хартії місцевого самоврядування 8 щодо питань місцевого значення, визначено, що органам i посадовим особам місцевого самоврядування, територіальним громадам надаються всі функції та повноваження, крім тих, які закріплені за органами державної влади Конституцією та законами України. Сьогодні проблематика законодавчого визначення переліку питань місцевого значення як основного об'єкта управлінської діяльності органів місцевого значення націлена на те, щоб в Україні функції та повноваження місцевого управління закріплювалися за предметним, а не традиційно-галузевим принципом. Цей підхід був спрямований не на територіальну громаду, тобто не на жителів, як цього вимагає Конституція України, а на сфери місцевого життя, у яких є компетентними органи цих територіальних громад, і їхні повноваження: виключні, власні (самоврядні), делеговані 9 . Ураховуючи, що територіальна громада -

8 Свропейська хартія місцевого самоврядування від 15.10.1985. URL: https://zakon.rada.gov.ua/laws/show/994_036 (дата звернення: 02.03.2020).

${ }^{9}$ Батанов О. Проблеми конституційної регламентації компетенції місцевого самоврядування в Україні та зарубіжних країнах. Право України. 2015. № 9. С. 104-112. 
основний носій функцій і повноважень місцевого самоврядування, вона, на думку вчених, має реалізовувати політичну, економічну, соціальну, культурну та екологічну об'єктні функції ${ }^{10}$.

Наступна проблема перебуває в площині ефективного управління питаннями місцевого значення. а саме забезпечення для цього методологічного підгрунтя. Термін «адміністрація», яке походить від латинського ministrare («служити»), указує на підпорядкованість політичній владі та служіння публічним інтересам як головне завдання в діяльності публічної адміністрації та публічній службі ${ }^{11}$. Узагальнюючи, можна стверджувати, що публічним інтересом місцевого управління $є$ питання задоволення інтересів територіальних громад. Сьогодні один із показників ефективного місцевого управління - це спроможність територіальних громад, адже спроможна територіальна громада - це територіальні громади сіл (селищ, міст), які в результаті добровільного об'єднання здатні самостійно або через відповідні органи місцевого самоврядування забезпечити належний рівень надання послуг, зокрема, у сфері освіти, культури, охорони здоров'я, соціального захисту, житловокомунального господарства, 3 урахуванням кадрових ресурсів, фінансового забезпечення та розвитку інфраструктури відповідної адміністративно-територіальної одиниці.

Реалізацією предметно-територіального підходу $\epsilon$ питання визначення й закріплення об'єктів управління, у тому числі питань місцевого значення, органів публічної влади, який утілено в Постанові Кабінету Міністрів України «Про затвердження Типового положення про агенцію регіонального розвитку» від 16 лютого 2016 року № $258^{12}$. Агенції регіонального розвитку вже успішно функціонують у таких провідних країнах, як Німеччина, Франція, Великобританія, Польща, Австралія, Канада. У регіональних стратегіях розвитку більшість областей передбачає створення агенції регіонального розвитку, яка допомагатиме місцевій владі

${ }^{10}$ Проблеми реалізації Конституції України: теорія і практика : монографія / за заг. ред. В.Ф. Погорілко. Київ : Ін-т держави і права ім. В.М. Корецького НАН України: А.С.К., 2003. 652 с.

11 Izdebski H., Kulesza M. Administracja publiczna. Zagadnienia ogolne. Warszawa : LIBER, 1999. S. 17-23.

12 Про затвердження Типового положення про агенцію регіонального розвитку : Постанова Кабінету Міністрів України від 11 лютого 2016 р. № 258. URL: http://www.kmu.gov.ua/control/uk/cardnpd?docid=248941325 (дата звернення: 02.03.2020). 
втілювати стратегію і здійснювати заходи, передбачені планом з іiі реалізації.

Процеси створення й діяльності Агенції регіонального розвитку відбуваються відповідно до статей 6 і 39 Закону України «Про місцеві державні адміністрації»"13, статті 19 Закону України «Про засади державної регіональної політики» ${ }^{14}$, Постанови Кабінету Міністрів України «Про затвердження Типового положення про агенцію регіонального розвитку» від 11 лютого 2016 року № $258^{15}$, рішень обласних рад щодо Регіональних стратегій розвитку областей, на основі партнерства між приватним, державним i громадським секторами 3 метою реалізації проектів розвитку територій із залученням внутрішніх і зовнішніх ресурсів.

Агенції мають стати осередками співпраці між державним, приватним і громадським секторами, оскільки їх засновниками $\epsilon$ обласні державні адміністрації, відповідні ради та неурядові організації як співзасновники. Результатом діяльності агенцій має бути задоволення публічних інтересів, тобто інтересів громадян, органів публічної влади, підприємств, установ тощо.

За даними Міністерства розвитку громад та територій України ${ }^{16}$, сьогодні у 22 регіонах уже прийняли рішення про створення агенцій регіонального розвитку. Загалом 18 агенцій уже працюють або доформовуються. Для порівняння зазначимо, що станом на червень 2018 року 12 областей подали інформацію щодо їх створення. Найуспішніші агенції функціонують у Черкаській, Житомирській, Закарпатській і Вінницькій областях. Основними функціями агенцій визначено ефективне використання можливостей для регіонального розвитку, залучення до реалізацій проектів розвитку територій

${ }^{13}$ Про місцеві державні адміністрації : Закон України від 09.04.1999 № 586XIV. URL: http://zakon2.rada.gov.ua/laws/show/586-14 (дата звернення: 02.03.2020).

14 Про засади державної регіональної політики : Закон України від 05.02.2015 № 156-VIII. URL: http://zakon2.rada.gov.ua/laws/show/156-19 (дата звернення: 02.03.2020).

15 Про затвердження Типового положення про агенцію регіонального розвитку : Постанова Кабінету Міністрів України від 11 лютого 2016 р. № 258. URL: $\quad$ http://www.kmu.gov.ua/control/uk/cardnpd?docid=248941325 (дата звернення: 02.03.2020).

${ }^{16}$ Міністерство розвитку громад та територій України. Офіційний веб-сайт. URL: http://www.minregion.gov.ua (дата звернення: 02.03.2020). 
місцевої влади, бізнесу та громадськості. 32014 року державна підтримка регіонів і громад збільшилася в 40 разів.

Перший заступник міністра повідомив, що Мінрегіон надаватиме фінансову підтримку діяльності агенцій регіонального розвитку в рамках секторальної бюджетної підтримки Європейського Союзу за напрямом «Підвищення ефективності управління регіональним розвитком», сприятиме реалізації проектів регіональних стратегій розвитку. Ці стратегії мають бути розроблені на засадах європейської методології смарт-спеціалізації та реалізації комплексних проектів міжрегіонального співробітництва. До процесу розроблення регіональних стратегій мають бути залучені агенції регіонального розвитку. Саме вони повинні забезпечити координацію та об'єднання зусиль органів влади, бізнесу та громадськості, зробити їх партнерами ${ }^{17}$.

3 березня 2016 року діє Міжвідомча координаційна комісія 3 питань регіонального розвитку за участі керівників центральних і місцевих органів виконавчої влади, всеукраїнських асоціацій, наукових установ та інших учасників, задіяних у сфері регіонального розвитку. Комісія як консультативно-дорадчий орган Кабінету Міністрів координує діяльність органів виконавчої влади під час формування й реалізації державної регіональної політики. Це впливає на запровадження територіально-об'єктного підходу, за якого міністерства спрямовуватимуть свої секторальні політики та заходи на розвиток регіонів з урахуванням специфіки кожного з них.

Узагальнюючи наведений матеріал, зазначимо основні проблеми здійснення місцевого управління в Україні сьогодні, які потребують наукового вивчення та практичного вирішення, серед них:

- ефективне забезпечення надання публічних послуг населенню місцевою та центральною владою на партнерських засадах;

-наявність потреби розмежування функцій кожного суб'єкта місцевого управління. Проблемою тут $є$ політичні питання розмежування влади, адже суб'єктами часто є учасники з різним статусом, відповідно, з різним функціональним і компетенційним навантаженням;

17 Ресурсний центр зі сталого місцевого розвитку. Украӥнська асоиіація районних та обласних рад. URL: https://rozvytok.in.ua/4295-dlia-kozhnoi-oblastiefektyvna-ahentsiia-rehionalnoho-rozvytku-tse-vzhe-neobkhidnist-viacheslav-nehoda (дата звернення: 02.03.2020). 
-інтегрування державних і недержавних утворень породжує цілу низку питань щодо їх взаємодії, насамперед у частині відповідальності, наявних повноважень, функцій;

-наявність і розвиток суб'єктно-статусних характеристик у місцевому управлінні;

- розподіл функцій суб'єктів місцевого управління та їх інституційне закріплення.

Основними проблемними питаннями в процесах нормативноправового забезпечення місцевого управління $€$ :

-відсутність законодавчого визначення питань місцевого значення;

- існування конституційно-декларативного визначення предметів управління на місцевому рівні спричинює проблемні ситуації як у практиці, так і в теорії публічного управління;

-наявність різних співвідношень управлінського впливу суб'єктів управління на місцевому рівні;

-повноваження місцевого самоврядування залишаються закріпленими за традиційно-галузевим принципом;

-зазвичай питання врахування публічного інтересу, а в цьому разі інтересу територіальної громади, має дорадчий, консультативний характер;

-виявлення, фіксація та розподіл конкретних предметів управління на місцевому рівні (у вужчому сенсі - за об'єктним і територіальним принципом) за учасниками місцевого управління;

-проблема інституалізації в нормативному полі суб'єктності та статусних характеристик на місцевому рівні;

-проблема врахування специфіки й потенціалу локальної території.

Актуальні натепер тенденції місцевого управління, які стосуються становлення концептуальних засад сучасного управління в довгостроковій перспективі:

-ствердження концептуальних засад суб'єктно-статусних характеристик у місцевому управлінні, які характеризуються прискоренням процесів демократизації влади, посиленням партнерських, договірних підходів муж суб'єктами, розвитком різноманітних форм і методів взаємодії з населенням, посиленням ролі участі громадян у здійснення владних повноважень;

- розвиток управлінських зв'язків, взаємовідносин між суб'єктами місцевого управління; 
-становлення основних принципів, закономірностей, законів місцевого управління, що створює інноваційне підгрунтя для ефективного управління на місцях;

- формування методологічно-організаційної основи відповідно до запитів сьогодення з урахуваннях інноваційних тенденцій, нових понять, категорій і методологічних інструментів.

\section{2. Рекомендації щодо вирішення проблем місцевого значення: теоретико-методологічний аспект}

Аналіз стану здійснення місцевого управління виявив низку проблем, які лежать у різних галузях і площинах наук, сфер, відносин. Тому до їх вирішення потрібно підходити лише комплексно, 3 урахуванням позицій усіх учасників здійснення місцевого управління та чинних норм права.

У науково-дослідницькому контексті основоположним $\epsilon$ здійснення управлінської діяльності на місцевому рівні на концептуальних засадах місцевого управління. Розвиток теорії місцевого управління нерозривно пов'язаний загалом із теорією публічного управління, що передбачає вплив інших теорій i концепцій, які перебувають у полі зору науковців і практиків систем управління, серед яких - теорія вільної громади, громадівська теорія, концепція політичних мереж, концепція Public administration, концепція управління за цілями, результатами, концепція «Governance» тощо, а також основні моделі територіальної організації влади. Основою здійснення місцевого управління є такі базові функції управління, як планування, розпорядництво, організація, координація, контроль. В Україні сформовані концепцією адміністративного управління принципи управління відображено в побудові ієрархічних взаємозв'язків між суб'єктами публічної влади, централізації, поділі праці. У методологічному плані потрібно вдосконалювати інструментарій для запровадження якісного методологічного забезпечення здійснення місцевого управління. Методологічного доопрацювання потребують підходи до виявлення та діагностування проблемних ситуацій сфери місцевого управління, які проаналізовані у статті.

Доцільно розробити ефективний спосіб комунікації між усіма суб'єктами місцевого управління, споживачами місцевих послуг, експертним середовищем. У цьому контексті важлива інформаційна підтримка управлінської діяльності й формування єдиного інформаційного простору для можливості. 
Запровадження практики проведення науково-експертних оцінок і досліджень щодо здійснення місцевого управління $є$ актуальним у контексті виявлення проблемних питань, підвищення рівня ефективності управління, раціонального використання ресурсів місцевих громад. Але практика здійснення місцевого управління вказує на низький рівень проведення таких оцінок і залучення експертів здебільшого через некомпетентність прийнятих управлінських рішень, нерозуміння потреби в таких оцінках i дослідженнях, проблеми фінансування тощо. Доцільно запровадити систематичні семінари національного та місцевого рівня для управлінців інституцій, які залучені до вирішення питань місцевого значення, що консолідувало б зусилля, виключило дублювання функцій, дало змогу розмежувати повноваження.

Практично відсутні розробки й експертні продукти наукового характеру для здійснення ефективного управління на місцевому рівні. Локальні території, об'єкти місцевого промислового, історичного та іншого значення, навколишнє середовище, історичні пам'ятки, національні традиції тощо становлять неоціненну основу для розвитку територій та громад України.

Також потребує визначення практична потреба органів місцевого управління в науковому супроводі вирішення проблем місцевого значення.

У широкому змістовому значенні місцеві публічні інтереси можна поділити на групи, що виникають у сфері місцевого самоврядування: інтереси території; інтереси територіальної громади; інтереси груп самоорганізації; інтереси конкретного жителя. У питаннях визначення пріоритетності питань місцевого значення доцільно закріпити критерій визначення пріоритетів їх розвитку, затвердження найвагоміших правових актів, посилити роль місцевої законотворчості.

Запровадження практики експертних і наукових досліджень щодо процесів здійснення місцевого управління, вирішення проблем локального характеру не врегульовано законодавчо, вирішується здебільшого на розсуд органів публічної влади, інших інституцій, у тому числі різних форм власності, що часто ставить під сумнів урахування публічного інтересу й ефективність здійснення управління загалом.

Ефективне управління на конкретній території неможливо здійснити без визначення об'єктів управління, відповідно, компентенцій кожного суб'єкта управління, закріплених у правовому полі. Результатом здійснення ефективного місцевого 
управління є формування локальної компетенції для всіх суб'єктів, зокрема для органів публічної влади та їх посадових осіб, яка фіксується в їхніх повноваженнях і компетенціях їх посадових осіб.

Застосування системного підходу до місцевого управління виокремило такі його підсистеми, як організаційно-правова, функціонально-компетенційна, інституційна, що є похідними від функцій системи, тобто вони формують сутність системи місцевого управління. Отже, орієнтуючись на головну мету, зазначені підсистеми виконують специфічні функції, цим самим забезпечують досягнення специфічної мети кожної підсистеми. Тобто застосування системного підходу до місцевого управління визначає, що діяльність системи місцевого управління, ії компонентів для досягнення мети, дії із застосуванням певних засобів $є$ ні що інше, як взаємодія функцій системи та ії складників.

Обгрунтовано, що функціями органів місцевої влади є основні напрями їхньої діяльності, у яких виявляється їх сутність і призначення в державному механізмі. Визначено, що основними передумовами управлінської діяльності 3 позиції функціонування місцевого управління $є$ такі: напрями діяльності публічних інституцій, які націлені на питання місцевого значення; характеристика здійснення місцевого управління, іiі сервісний характер; задоволення публічного інтересу, тобто інтересу соціальної спільноти, який визначається потребою суспільства; компетенція інституції, що здійснює цю функцію; охоплення основних сфер суспільного життя: адміністративно-політичної, соціально-гуманітарної, економічної. Функції місцевого управління мають постійний характер щодо свого виконання, оперативну ознаку діяльності, тому завдання й обов'язки управлінця мають відповідати завданням i функціям інституції. Базовим положенням щодо формування місцевого управління в контексті розкриття його функцій на місцевому рівні $є$ визначена в законодавчому полі позиція, за якої суб'єкт є виконавцем функцій, зокрема управлінських, організаційно-розпорядчих, консультативнодорадчих.

Урахування функціонально-компетенційного складника управлінської діяльності визначено та проаналізовано на прикладі окремих елементів системи місцевого управління: статус i компетенція суб'єктів, компетенційний складник діяльності управлінців.

Оскільки місцеве управління задіює систему суб'єктів, які виконують місцеві функції, то потребує вирішення систематизація 
проблемних питань усіх суб'єктів щодо вирішення питань місцевого значення.

Управлінська діяльність як процес розвитку за необхідну умову визначає розвиток місцевого управління на основі сформованих принципів управлінської діяльності. Принципи, які є об'єктивними за змістом і суб'єктивними за формою, несуть досить вагоме гносеологічне, методологічне, інформативне й організаційноуправлінське навантаження та $є$ основою системогенезу державноуправлінської діяльності. У вузькому розумінні ефективність системогенезу інституту державної служби ефективна лише тоді, коли принципи не лише декларуються, а ними безпосередньо керуються на практиці, ними пронизана вся професійна діяльність ${ }^{18}$.

У теорії управління принципи розглядаються як прояви закономірностей, відношення або взаємозв'язки суспільнополітичного характеру й інших груп елементів управління, відображені у вигляді певного наукового положення, що застосовується в теоретичній і практичній діяльності людей у сфері управління.

Принципи управління грунтуються на онтологічних, гносеологічних і методологічних аспектах управлінської діяльності, відображають найсуттєвіші, основні, об'єктивно необхідні закономірності, відносини та взаємозв'язки в управлінні.

Найвідоміші принципи управління, які застосовані тією чи іншою мірою в місцевому управлінні: об'єктивність (необхідність дотримання в усіх управлінських процесах вимог об’єктивних закономірностей суспільного розвитку); демократизм (визначає роль народу як носія й джерела влади); правова регламентація (необхідність законодавчого визначення основних цілей, функцій, структур, принципів управління); поділ влади (передбачає поділ влади на три гілки - законодавчу, виконавчу та судову); публічність (забезпечує взаємозв'язок органів державного управління із суспільством, громадянами) ${ }^{19}$.

Часто в літературі аналізуються основні принципи, на яких грунтується державотворення в Україні та які безпосередньо

18 Акімов О.О. Професійна діяльність державних службовців та посадових осіб місцевого самоврядування: психологічні аспекти управління кадрами. Державне управління та місиеве самоврядування. 2016. Вип. 3. С. 106-113.

19 Кузнецов А.О. Принцип. Енциклопедичний словник 3 державного управління / уклад. : Ю.П. Сурмін, В.Д. Бакуменко, А.М. Михненко та ін. ; за ред. Ю.В. Ковбасюка, В.П. Трощинського, Ю.П. Сурміна. Київ : НАДУ, 2010. 820 c. C. 561. 
пов'язані з принципами управління. Зокрема, принцип гуманізму у формуванні й діяльності механізму держави базується на конституційно визначеній ознаці України як соціальної держави. Ïї політика спрямована на задоволення духовних і матеріальних потреб особистості, забезпечення добробуту людини й суспільства. За загальною класифікацією, принципи державного управління поділяють так: структурно-цільові (узгодженість цілей, взаємодоповнюваність цілей, підпорядкованість локальних цілей загальним тощо); структурно-функціональні (диференціації та фіксації, концентрації, комбінування, відповідності тощо); структурно-організаційні (єдності системи державної влади, централізації й децентралізації, територіально-галузевий принцип тощо); структурно-процесуальні (конкретизації управлінської діяльності, відповідності елементів (методів, форм і стадій) управлінської діяльності їх функціям) $)^{20}$.

Тому з позиції теоретико-методологічного забезпечення виявлені проблеми місцевого управління, які актуалізують їх систематизацію в гносеологічному аспекті. Визначено, що потребують вирішення питання вибору систематизуючих критеріїв в управлінській діяльності, зокрема інституалізації суб'єктів управління та питань місцевого значення; взаємозв'язки складників системи місцевого управління, формування визначальних факторів розвитку управлінської діяльності. Щоб вирішити проблеми місцевого управління в гносеологічному аспекті доцільно:

-удосконалити науково-методологічне забезпечення управлінської діяльності, зокрема питання розроблення основних принципів, мети, об'єктного та суб'єктного складників;

-виявлення основних напрямів і функцій здійснення управлінської діяльності;

-залучити інноваційні та ефективні практики здійснення місцевого управління, зокрема, використавши зарубіжний досвід.

3'ясовано, що суб'єктний склад правовідносин у місцевому управлінні характеризується різним інституційним і статусним наповненням, що потребує нормативно-правового забезпечення та наукової підтримки. Суб'єктний склад правовідносин місцевого управління у владному контексті формується органами державної влади, органами місцевого самоврядування та їх посадовими особами. Статус суб'єктів владних повноважень $є$ однією 3 основних ознак для питань визначення, формування й реалізації

${ }^{20}$ Старилов Ю.Н. Служебное право. Москва : БЕК, 1996. 683 с. 
повноважень органів місцевої влади. Законодавець визначив суб'єктний складник як орган публічної влади, їх посадову чи службову особа або інший суб'єкт, який здійснює владні управлінські функції на основі законодавства. Визначено, що суб'єкт управління - це теж система, яка наділена певною компетенцією і державно-владними повноваженнями, що дають їй змогу здійснювати управлінський вплив у форматі керівних команд чи рішень, обов'язкових для виконання, тобто це система, що управляє.

Виявлено через аналіз нормативно-правової основи діяльності суб'єктів владних повноважень базову ознаку, за якою набуття й реалізація владних повноважень $є$ необхідною передумовою до здійснення правовідносин місцевого управління. У контексті інституційного чинника розвитку системи управлінської діяльності, беззаперечно, основоположним є чинний конституційний поділ влади. Формування повноважень суб'єктного складу правовідносин у місцевому управлінні здійснюється відповідно до наявних рівнів вертикалі влади, партнерської участі, за принципом паритетності. Пропонується використати критерій організаційно-правового рівня, за яким розвиток суб' єктного складу місцевого управління виявлено з позиції наявного структурного складу та компетенцій, визначених у нормативному полі.

Проаналізовано деякі особливості й недоліки інституційного та статусного характеру у формуванні суб'єктного складу правовідносин у державному управлінні. Наявність різних підходів до формування статусних характеристик органів місцевої влади передбачає різне змістове наповнення правовідносин у частині суб'єктного складу. Набуття особливих, спеціальних та інших статусів формується на підставі потреби виконання відповідних публічних функцій. Виявлено, що суб'єкти здійснення місцевого управління перебувають у різних статусах, це формує різне змістове наповнення управлінсько-правових правовідносин у частині суб'єктного складу.

Аналіз суб'єктного складу правовідносин указує на необхідність вивчення критеріїв розподілу суб'єктів владних повноважень за їх видами, статусними характеристиками, способами та принципами правовідносин управління; здійснення аналізу етапів формування й реалізацій компетенцій учасників управління; визначення рівнів управлінського впливу на розвиток складників системи місцевого управління. 
Методики здійснення оцінювання щодо питань здійснення місцевого управління може впроваджуватися в основних напрямах:

- функціонально-компетенційному (оскільки окреслює функції посад управлінців, виявляє компетенції, визначає напрями діяльності, актуалізує повноваження, окреслює заохочення, гарантії, відповідальність)

-компетентнісному (сприяє формуванню та розвитку вмінь, навичок, особистісних якостей; визначає рівень професійної компетентності; виявляе потреби компетентнісних аспектів у професійній діяльності; сприяє розвитку професійних навчальних програм);

-структурно-організаційному (дає змогу виявити структурні зміни в повноваженнях, організаційній структурі, виявляє деструктивні зміни в розподілі повноважень, сприяє змістовому наповненню посади).

\section{ВИСНОВКИ}

У статті проаналізовано й наведено проблемні питання місцевого управління, процесів його здійснення в Україні та запропоновано можливі шляхи їх вирішення 3 позиції науково-дослідницького i практичного підходу. Для досягнення мети визначено два завдання, аналіз яких дав змогу сформувати такі висновки.

На основі аналізу стану та проблем здійснення місцевого управління, тенденцій розвитку громад i територій, стану реформування місцевого управління виявлено низку проблемних питань, які можна сформувати в такі блоки:

- проблеми нормативного забезпечення;

- проблеми інституційності в управлінських взаємовідносинах;

- проблеми організаційно-функціонального характеру;

-проблеми формування об'єкта управління (питань місцевого значення, предмета компетенцій органів публічної влади тощо).

На основі здійсненого аналізу надано рекомендації щодо вирішення проблемних питань, пов'язаних зі здійсненням управлінської діяльності на місцевому рівні. 3 позиції науководослідницького підходу рекомендації стосуються методологічних розробок щодо виявлення та діагностування проблемних ситуацій сфери здійснення управлінської діяльності на місцевому рівні; застосування ефективних способів комунікації між усіма суб'єктами місцевого управління; запровадження практики проведення науково-експертних оцінок і досліджень щодо здійснення місцевого 
управління. 3 позиції практичного складника здійснення управлінської діяльності на місцевому рівні запропоновано: вирішити недоліки інституційного та статусного характеру у формуванні суб'єктного складу правовідносин через застосування інноваційних підходів до формування статусних характеристик органів місцевої влади, які передбачають різне змістове наповнення правовідносин у частині суб'єктного складу. Запропоновано формувати особливі, спеціальні та інші статуси суб'єктів місцевого управління на підставі потреби виконання відповідних публічних функцій. Інституалізацію здійснення місцевого управління рекомендовано запровадити через систему суб'єктів, які виконують місцеві функції із застосування систематизації проблемних питань усіх суб'єктів управління в контексті вирішення питань місцевого значення та визначення предметів управління.

Як підсумок зазначимо, що отримані результати дослідження такі: здійснено узагальнення щодо основних проблемних питань місцевого управління та запропоновано шляхи їх вирішення; вирішення проблемних питань розподілено за складниками: у практиці діяльності з позиції практичного складника, у науковій практиці - 3 позиції науково-дослідницького складника. Набули подальшого розвитку інституційний, територіально-орієнтований, галузевий аспекти вирішення проблемних питань, пов'язаних зі здійсненням управлінської діяльності на місцевому рівні.

\section{АНОТАЦІя}

У статті проаналізовано стан і проблеми місцевого управління в Україні та надано рекомендації щодо вирішення проблем місцевого значення 3 позиції застосування науково-дослідницького й практичного підходів. Виявлені проблеми місцевого управління сформовано в такі блоки: проблеми нормативного забезпечення; проблеми інституційності в управлінських взаємовідносинах; проблеми організаційно-функціонального характеру; проблеми формування об'єкту управління. За допомогою науково-дослідницького підходу рекомендовано застосовувати методологічні розробки щодо виявлення й діагностування проблемних ситуацій сфери здійснення управлінської діяльності на місцевому рівні. Актуалізовано проблеми інституційного та статусного характеру у формуванні суб'єктного складу правовідносин 3 можливістю застосування інноваційних підходів до формування статусних характеристик органів місцевої влади. Запропоновано формувати особливі, спеціальні й інші статуси суб'єктів місцевого управління на 
підставі потреби виконання відповідних публічних функцій i відповідно до предмета управління. Для визначення об'єктів місцевого управління та їх змісту запропоновано такі критерії: компетенційний критерій (об'єкти перебувають у компетенціях органів місцевого управління); територіальний критерій (об'єкти перебувають у межах території відповідної території); предметний критерій (об'єкти мають виражену предметну форму, тобто матеріальне, процедурне, управлінське визначення); процедурний критерій (вирішення питань щодо об'єктів управління передбачає управлінську дію). Застосовано системний підхід до аналізу місцевого управління, який охопив такі його підсистеми, як організаційно-правову, функціональнокомпетенційну, інституційну, що формують зміст системи місцевого управління.

\section{ЛІТЕРАТУРА}

1. Про затвердження Методики формування спроможних територіальних громад : Постанова Кабінету Міністрів України від 08.04.2015 № 214. URL: http://zakon2.rada.gov.ua/laws/show/2142015-\%D0\%BF/paran10\#n10 (дата звернення: 02.03.2020).

2. Карпа М.І. Формування компетенції органів публічної влади: територіально-орієнтований підхід. Ефективність державного управління: збірник наукових праць / ЛРІДУ НАДУ. 2017. Вип. 3. C. 213-222.

3. Реформа децентралізації завершиться в 2020 році проведенням восени місцевих виборів на новій територіальній основі громад. Єдиний веб-портал органів виконавчої влади України. URL: https://www.kmu.gov.ua/news/reforma-decentralizaciyizavershitsya-v-2020-roci-provedennyam-voseni-miscevih-viboriv-nanovij-teritorialnij-osnovi-gromad (дата звернення: 02.03.2020).

4. Реформа децентралізації. Єдиний веб-портал органів виконавчої влади України. URL: https://www.kmu.gov.ua/ua/diyalnist/ reformi/reforma-decentralizaciyi (дата звернення: 02.03.2020).

5. Офіційний веб-сайт Державної казначейської служби України. URL: https://www.treasury.gov.ua/ua/kaznachejstvoinformuye/obyednani-teritorialni-gromadi (дата звернення: 02.03.2020).

6. Конституція України : Закон від 28.06.1996 № 254к/96-ВР. URL: http://zakon3.rada.gov.ua/laws/show/254к/96-вр (дата звернення: 02.03.2020).

7. Рішення Коституційного Суду України у справі за конституційним поданням 139 народних депутатів України 
від 27.12.2001 № 20-рп/2001. URL: http://zakon3.rada.gov.ua/laws/ show/v020p710-01 (дата звернення: 02.03.2020).

8. Європейська хартія місцевого самоврядування від 15.10.1985. URL: https://zakon.rada.gov.ua/laws/show/994_036 (дата звернення: 02.03.2020).

9. Батанов О. Проблеми конституційної регламентації компетенції місцевого самоврядування в Україні та зарубіжних країнах. Право Украӥни. 2015. № 9. С. 104-112.

10. Проблеми реалізації Конституції України: теорія і практика : монографія / за заг. ред. В.Ф. Погорілко. Київ : Ін-т держави i права ім. В.М. Корецького НАН України: А.С.К., 2003. 652 с.

11. Izdebski H., Kulesza M. Administracja publiczna. Zagadnienia ogolne. Warszawa : LIBER, 1999. S. 17-23.

12. Про затвердження Типового положення про агенцію регіонального розвитку : Постанова Кабінету Міністрів України від 11 лютого 2016 р. № 258. URL: http://www.kmu.gov.ua/control/uk/ cardnpd?docid=248941325 (дата звернення: 02.03.2020).

13. Про місцеві державні адміністрації : Закон України від 09.04.1999 № 586-XIV. URL: http://zakon2.rada.gov.ua/laws/ show/586-14 (дата звернення: 02.03.2020).

14. Про засади державної регіональної політики : Закон України від 05.02.2015 № 156-VIII. URL: http://zakon2.rada.gov.ua/ laws/show/156-19 (дата звернення: 02.03.2020).

15. Про затвердження Типового положення про агенцію регіонального розвитку : Постанова Кабінету Міністрів України від 11 лютого 2016 p. № 258. URL: http://www.kmu.gov.ua/control/uk/ cardnpd?docid=248941325 (дата звернення: 02.03.2020).

16. Міністерство розвитку громад та територій України. Офіиійний веб-сайт. URL: http://www.minregion.gov.ua (дата звернення: 02.03.2020).

17. Ресурсний центр зі сталого місцевого розвитку. Українська асоціація районних та обласних рад. URL: https://rozvytok.in.ua/ 4295-dlia-kozhnoi-oblasti-efektyvna-ahentsiia-rehionalnoho-rozvytkutse-vzhe-neobkhidnist-viacheslav-nehoda (дата звернення: 02.03.2020).

18. Акімов О.О. Професійна діяльність державних службовців та посадових осіб місцевого самоврядування: психологічні аспекти управління кадрами. Державне управління та місцеве самоврядування. 2016. Вип. 3. С. 106-113.

19. Кузнецов А.О. Принцип. Енщиклопедичний словник 3 державного управління / уклад. : Ю.П. Сурмін, В.Д. Бакуменко, 
А.М. Михненко та ін. ; за ред. Ю.В. Ковбасюка, В.П. Трощинського, Ю.П. Сурміна. Київ : НАДУ, 2010. 820 с. С. 561.

20. Старилов Ю.Н. Служебное право. Москва : БЕК, 1996. $683 \mathrm{c}$.

\section{Information about authors:}

Karpa M. I.,

Doctor of Public Administration, Associate Professor of the Department of Management and Business Administration Vasyl Stefanyk Precarpathian National University 57, Shevchenka Str., 76000, Ivano-Frankivsk, Ukraine

Akimov 0. O., $\mathrm{PhD}$ in Public Administration, Associate Professor, Honoured Economist of Ukraine, Professor of the Department of Public Administration Interregional Academy of Personnel Management 2, Frometivska Str., 03039, Kyiv, Ukraine 